УДК: 378.014.543

JEL: $H 75$

Обушний Сергій Миколайович

кандидат економічних наук, заступник декана

факультету інформаційних технологій та управління

Київського університету імені Бориса Грінченка,

м. Київ, Україна

ORCID ID: 0000-0001-6936-955X

e-mail: s.obushnyi@kubg.edu.ua

Кучеровська Вікторія Олександрівна

здобувач ступеня магістр,

Київський університет імені Бориса Грінченка,

м. Київ, Україна

e-mail: v.kucherovska@gmail.com

\title{
УДОСКОНАЛЕННЯ ФІНАНСУВАННЯ ОСВІТНЬОЇ ДІЯЛЬНОСТІ ЗАКЛАДІВ ВИЩОЇ ОСВІТИ В УКРАЇНІ
}

Анотація. У статті розглянуті основні задачі фінансового забезпечення діяльності закладів вищої школи, дана характеристика та аналіз чинної системи, розроблено рекомендації врегулювання рівня фінансового забезпечення окремого закладу вищої освіти та системи вищої освіти в цілому.

При дослідженні виявлено, що сфера діяльності закладів вищої освіти не має можливості розвиватися без належного фінансування і потребує постійних вкладень. Процес реформування системи вищої освіти не є простим, бо не зважаючи на оновлення, нові вимоги та потреби, фінансування залишається достатньо низьким. Через те все більшої актуальності набуває пошук альтернативних джерел фінансування закладів вищої освіти. Вивчення недоліків системи фінансування закладів вищої освіти дає змогу виокремити перелік пропозицій, щодо трансформування фінансового стану.

На основі проаналізованого досвіду закордонних країн, окреслено умови, за яких його можливо імплементувати для українського суспільства; запропоновано ряд заходів для оцінки результативності фінансового механізму закладів вищої освіти; враховуючи порівняльний аналіз та вплив економічних чинників.

Визначено, що задля подолання проблем фінансування освітньої діяльності закладів вищої освіти потрібно реалізувати комплекс заходів, а саме: розробити систему трансформації внутрішніх процесів, внести зміни до законодавчих документів, в тому числі й до порядку фінансування; розробити механізми визначення потреби у певних фахівцях через певні проміжки часу; вдосконалювати та розповсюджувати програми державного кредитування та субсидіювання.

Рух в напрямку сучасних економічних та соціальних зрушень, перехід до інноваційного типу економіки - це стовідсотково правильний шлях для нашої держави. Попри неабиякий тиск на систему вищої освіти та постійні вимоги необхідна концентрація всіх можливих зусиль у напрямку підвищення ефективності діяльності закладів вищої освіти. На державному рівні необхідне створення вимог для здійснення покладених на заклад вищої освіти обов'язків, долаючи тотальну нестачу фінансових ресурсів спрямованих у дану сферу.

Ключові слова: бюджетне фінансування; заклади вищої освіти; механізми фінансування; освітні послуги; фінансове забезпечення.

DOI: http://doi.org/10.32750/2019-0206

\section{ВСТУП}

Постановка проблеми. Фінансове забезпечення системи освіти є основною умовою забезпечення якісно високого рівня освітніх послуг та підвищення рівня конкурентоспроможності закладів вищої освіти. Інтеграція України до світової спільноти ставить перед державою певні умови, які є ключовими компонентами національного багатства передових країн, а саме - інтелект, освіта та професіоналізм. Виходячи з цього, нам потрібно 
суттєво змінити підхід до ролі особистості в економічній, політичній та соціальній сферах суспільства.

Дослідження механізмів утворення та використання фінансових ресурсів має на меті виявлення альтернативних резервів та покращення ключових економічних показників діяльності закладів вищої освіти (далі - 3ВО). Для ефективного використання цих ресурсів необхідне вирахування оптимального співвідношення між бюджетними та позабюджетними коштами, а це можливо реалізувати шляхом реорганізації наявної структури.

На сьогодні, вивчення теоретичних, методологічних та методичних аспектів механізму формування та раціонального використання фінансових ресурсів ЗВО є достатньо актуальними, не в повній мірі вивчені, досліджені та узагальнені в умовах великої конкуренції на ринку освітніх послуг.

Аналіз останніх досліджень і публікацій. Питання вдосконалення системи вищої освіти, покращення якості надання освітніх послуг, модернізації підходів теоретичної та практичної підготовки, пошуку оптимальних шляхів фінансування освітньої діяльності закладів вищої освіти висвітлюються у роботах вітчизняних і закордонних вчених, серед яких варто виділити наступних: Антонова О.М., Бенедик Ю.Ю., Білінець М.Ю., Вернер Я., Джонстон Б., Сгорова І.Ю., Красільник О.В., Солеренко К., Стадний С.А., Тейлор Т., Тілак Дж., Усик В.І., Чирва О.Г., Шевальє Т. та інші.

Мета статті. Вивчення сильних та слабких сторін фінансування закладів вищої освіти, визначення їх потреб та формування пропозицій щодо вдосконалення системи фінансування освітньої діяльності закладів вищої освіти.

\section{РЕЗУЛЬТАТИ ДОСЛІДЖЕННЯ}

У більшості держав світу фінансова забезпеченість закладів вищої освіти є одним із визначальних факторів незалежності. Сучасні заклади вищої освіти для провадження освітньої діяльності потребують значних коштів, причому потреба в них постійно зростає. Тому першочергового значення набувають питання щодо джерел формування та забезпечення фінансовими ресурсами закладів вищої освіти.

Удосконалення системи вищої освіти в Україні передбачає покращення якості надання освітніх послуг, модернізації підходів теоретичної та практичної підготовки, виховання здобувачів освіти на загальнолюдських цінностях та патріотизмі і звичайно ж пошук релевантних методів фінансового забезпечення. Трансформація економічних підходів в Україні спричинила потребу до реформування системи вищої освіти. Ключовою перепоною на цьому шляху є неналежне фінансування, а саме брак коштів, спрямованих на розвиток закладів вищої освіти. Важливого значення набуває вивчення системи державного та приватного фінансування 3ВО, а також пошук альтернативних методів вдосконалення їх фінансового забезпечення.

Основними проблемами фінансування, що надалі стримують розвиток 3ВО, є:

- загальнодержавна тенденція до зменшення обсягу видатків на освіту;

- недосконалість законодавчої бази в частині бюджетного фінансування;

- відсутність прогнозування видатків та витрат;

- нестача відповідальності абітурієнтів при виборі майбутньої професії та закладу вищої освіти для подальшого навчання.

Проблеми вищої освіти є одною з найпоширеніших тем для обговорення. Система вищої освіти нашої країни завжди мала імідж високоякісної, у порівнянні з найближчими країнами-сусідами, проте відстежується тенденція послабленої уваги до технічного прогресу. До прикладу, в Польщі і Чехії деякі ЗВО є генераторами нововведень, це спричинює гостру потребу постійної підтримки та своєчасного оновлення матеріально- 
технічної бази. В Україні ж поширена практика використання застарілих, ще радянських фондів, для надання освітніх послуг.

Результатом створення механізму управління фінансовим забезпеченням ЗВО $\epsilon$ задоволення населення якісними та доступними освітніми послугами, працівників освіти - достойною заробітною платою, робочі місця - кваліфікованими фахівцями, а держава підвищення рівня економіки.

Ще у 2014 році запущено реформу державної політики України у сфері місцевого самоврядування (децентралізацію). Ії̈ основною метою є подолання великої кількості проблем державних установ, шляхом перерозподілу коштів на місця з метою запобігання неефективного розподілу бюджетних коштів, зокрема у сфері вищої освіти, через передання певної кількості повноважень місцевим органам влади. Та, як виявилося насправді, позитивний ефект прослідковувався не довго. Бюджетна децентралізація спричинила тенденцію зменшення питомої ваги видатків на освіту у бюджеті України та відповідне збільшення іiі у видатках місцевих бюджетів за усіма освітніми рівнями. Не дивлячись на всі умови за для покращення становища 3ВО, місцеві органи влади не були готові до самостійності у прийнятті рішень, в результаті чого кошти, які надходять майже не потрапляють до ЗВО. Це спричинено звичкою до того, що заклади вищої фінансуються Міністерством освіти і науки та через неправильне усвідомлення характеру витрат. У свідомості українців витрати на ЗВО розглядаються як складова соціальної політики, та у більшості розвинутих країн освіта розглядається як найефективніша інвестиція у людський капітал. Трансформація поглядів на значення вищої освіти для розвитку нації в цілому дозволить підвищити рівень вищої школи та вивести іiі в пріоритетні завдання держави, що в майбутньому сприятиме формуванню оновленої дієвої освітньої політики. Реформа освіти — явище не тільки освітнє, а й взагалі суспільне, зокрема економічне [4, С. 102]. Для виокремлення ключових напрямів покращення стану фінансового забезпечення закладів вищої освіти необхідно вивчити головні проблеми, що перешкоджають розвитку освітнього сектору.

В Україні таких перешкод декілька. По-перше, це метод фінансування «від оберненого». Недостатнє фінансування ЗВО спричинене невідповідністю державним стандартам, наданням освіти низької якості, недосконалою науково-дослідною активністю тощо. Очевидно, що зменшення фінансування вищої школи не сприяє покращенню реалізації діяльності на належному рівні, i поступово призведе до неминучого їх скорочення.

У нашій державі найбільш поширеною є практика економії фінансування на державних закладах освіти, натомість в розвинутих країнах в скрутні періоди проводиться ряд антикризових заходів з метою вирівняння фінансового стану ЗВО. Так, згідно з статистичними даними, починаючи з 2013/14 н.p., коли сума витрат на потреби вищої освіти у відсотках до загальних витрат на освіту становила 7,2\% від ВВП, 3 кожним роком ці показники ставали все меншими, й у 2016/17 н.р. вже становили 5,4\% відповідно (див. Рисунок 1).

Спостерігається, що замість підтримки в період фінансової кризи національні ЗВО мають працювати в умовах жорсткої економії, що негативно відбивається на якості надання освітніх послуг.

По-друге, недосконалість нормативної бази, в тому числі стосовно бюджетного фінансування освіти та науки. Проект бюджету на 2020 рік наочно демонструє, що головною метою фінансування ЗВО не $є$ підтримка та сприяння його розвитку, здебільшого статті витрат спрямовані на забезпечення оплати праці педагогічних, науково-педагогічних та наукових працівників, а також підтримка здобувачів наукових ступенів. Попри зазначене, більшість законодавчих норм, які мають регулювати та 
сприяти фінансуванню вищої освіти не дієві по причині невідповідності реальним можливостям держави та потребам освіти.

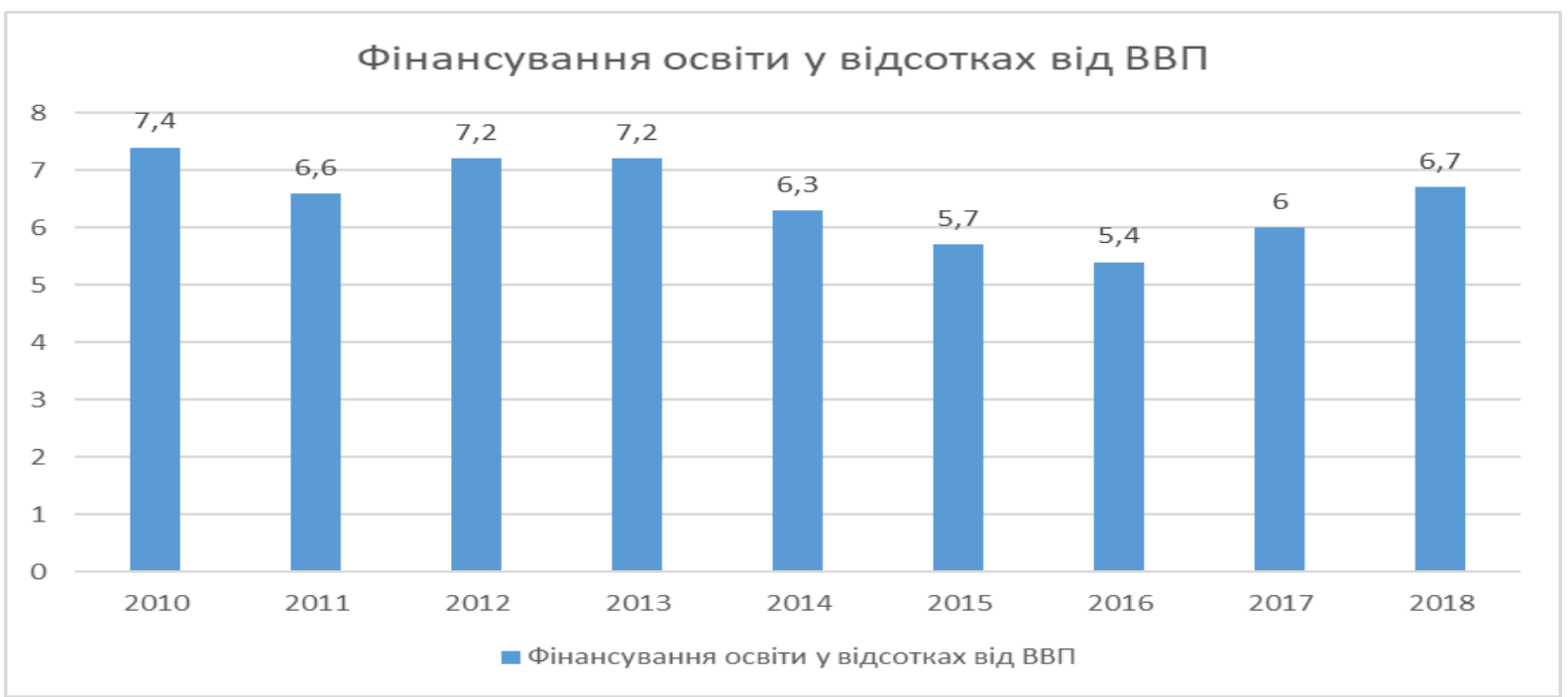

Рис 1. Фінансування освіти у відсотках від ВВП 2010 - 2018 рр.

Джерело: складено авторами на основі опрацювання даних із статистичних джерел [5-9].

Проблема розподілу бюджетних видатків на освіту і науку мусить вирішуватися, перш за все, на рівні прийняття Закону «Про державний бюджет» на відповідний рік. Необхідна розумна і збалансована стратегія фінансування науки та освіти, яка покаже, що кошти використовуються раціонально, продумано і прозоро. Така стратегія дозволить напрацювати необхідний рівень довіри між різними зацікавленими групами й відомствами в питаннях фінансування освіти [1].

По-третє, відсутність ефективного прогнозування обсягів фінансування вищої школи. Сьогодні обсяги фінансування вищої освіти плануються не відповідно до реальних потреб вищої школи, а 3 розрахунку залишкових коштів, на які можна претендувати з розрахунку на поточний Бюджет. Та все ж найважливішим фактором вважається обсяг фінансових відрахувань, а не ефективність їх розподілу. 3 таким підходом навіть надвелике фінансування не призведе до шалених змін та покращень і не зможе витягнути ЗВО зі стану «простою».

По-четверте, відсутність в абітурієнтів відповідальності перед вибором майбутньої професії. Ця тема тільки останнім часом набирає розголосу, проте досі не береться до уваги під час розгляду проблем браку коштів. При цьому, безвідповідальне ставлення здобувачів освіти до вибору спеціальності та закладу освіти, а, отже, в результаті й до процесу навчання, разом з повною пасивністю держави у напрямку вирішення подібних ситуацій є надзвичайно загрозливим чинником для економіки країни в цілому. Широкий спектр закладів освіти в Україні створив нездорові пільгові умови для вступу у ЗВО. Велика кількість абітурієнтів з середнім та низьким рівнем досягнень займає бюджетні місця, майже кожен студент може знайти 3ВО, що запропонує йому бюджетне місце та стипендію, принаймні на перший семестр. Це спричинене абсолютною відсутністю профорієнтаційних заходів та нерозумінням потреб ринку праці на предмет перспективних професій. Наслідком такої підготовки здобувачів освіти є тисячі випускників, на яких держава витратила кошти на підготовку, які після закінчення вищої школи не можуть або не хочуть працювати за обраним напрямком. 
Вивчення даних кількості студентів, що навчаються за кошти державного бюджету, а також тієї кількості з них, що після закінчення навчання пішли працювати за спеціальністю підтверджує викладені вище думки - лише менша половина з вказаних здобувачів отримали роботу після закінчення ЗВО (див. табл. 1).

Таблиия 1

Співвідношення кількості здобувачів освіти, що навчаються за кошти державного бюджету до кількості випускників, які працюють за спеціальністю, тис. осіб

\begin{tabular}{|c|c|c|c|c|c|c|c|c|c|}
\hline \multirow{2}{*}{ Показники } & \multicolumn{3}{|c|}{$\begin{array}{c}\text { 3ВО I - II } \\
\text { рівнів акредитації }\end{array}$} & \multicolumn{3}{|c|}{$\begin{array}{c}\text { ЗВО III - IV } \\
\text { рівнів акредитації }\end{array}$} & \multicolumn{3}{|c|}{$\begin{array}{c}\text { ЗВО I - IV } \\
\text { рівнів акредитації }\end{array}$} \\
\hline & $\begin{array}{l}2013- \\
2014\end{array}$ & $\begin{array}{l}2015- \\
2016\end{array}$ & $\begin{array}{l}2017- \\
2018\end{array}$ & $\begin{array}{l}2013- \\
2014\end{array}$ & $\begin{array}{c}2015- \\
2016\end{array}$ & $\begin{array}{l}2017- \\
2018\end{array}$ & $\begin{array}{l}2013- \\
2014\end{array}$ & $\begin{array}{l}2015- \\
2016\end{array}$ & $\begin{array}{l}2017- \\
2018\end{array}$ \\
\hline $\begin{array}{l}\text { Прийнято } \\
\text { студентів на } \\
\text { навчання }\end{array}$ & 328,99 & 230,11 & 208,60 & 1723,68 & 1375,16 & 1329,96 & 2052,68 & 1605,27 & 1538,56 \\
\hline $\begin{array}{l}3 \text { них за рахунок } \\
\text { державного } \\
\text { бюджету }\end{array}$ & 124,35 & 82,79 & 76,06 & 750,43 & 649,22 & 608,62 & 874,78 & 732,02 & 684,68 \\
\hline $\begin{array}{l}\text { Чисельність } \\
\text { випускників, які } \\
\text { працюють за } \\
\text { спеціальністю }\end{array}$ & 669,76 & 54,72 & 30,14 & 356,81 & 268,72 & 312,94 & 395,79 & 379,45 & 273,08 \\
\hline
\end{tabular}

Джерело: складено авторами на основі опраџювання даних із статистичних джерел [5-9].

При цьому варто наголосити, що статистичні дані не показують реальної ситуації даного питання, оскільки часто зустрічається факти спотворення інформації від ЗВО стосовно працевлаштування власних випускників.

Вивчивши недоліки системи фінансування закладів вищої освіти в Україні можна розробити ефективну модель розподілу державних коштів у сфері вищої освіти, здійснивши наступні кроки:

1. Розробка стратегії проведення заходів щодо «реабілітації» закладів вищої освіти.

В першу чергу варто створити та затвердити нормативно-правову базу, що допоможе регулювати та координувати діяльність держави у напрямку допомоги закладу вищої освіти виходу з кризового стану. Це питання $є$ надзвичайно нагальним, адже велика кількість ЗВО здійснює свою діяльність балансуючи на межі закриття через постійний брак коштів. Саме тому, для покращення фінансового стану 3ВО першочергово необхідно створити умови, в яких буде можливість спрямовувати виділені державою кошти на власний розвиток, а не на підтримку життєздатності. Враховуючи зазначене, пропонується здійснити заходи, що часто застосовуються в підприємницькій діяльності, а саме: чітко окреслити випадки та умови надання закладам вищої освіти державних дотацій, розробити принципи проведення модернізації 3 врахуванням індивідуальних особливостей ЗВО як суб'єкта діяльності. Цей метод буде ефективним, адже структура вищої школи за своєю сутністю максимально наближена до підприємства (ЗВО впроваджує діяльність, активно співпрацюючи з ринком праці, має власну продукцію (освіта) та кошти - бюджет).

Таким чином, ми бачимо що запобігання 3 «банкрутства» 3 ВО має відбуватись шляхом застосування подібних заходів, що мають місце у випадку банкрутства підприємства. А різноманітний спектр економічних методів для прогнозування ймовірності банкрутства, при належному використанні дозволить не допустити кризовий стан 3ВО. 

3BO.

2. Внесення змін до нормативно-правової бази, а саме, до системи бюджетування

В умовах пошуку шляхів до покращення загального фінансового стану системи вищої освіти, пропонується розглянути іiі як привабливий об'єкт інвестицій. Цей метод полягає в пошуку шляхів отримання позабюджетних коштів та інвестицій, які можуть надходити до 3ВО від інвесторів та співпраці з приватними структурами. Підтримка інноваційного і венчурного бізнесу, а також заохочення того бізнесу, який готовий інвестувати в наукові розробки, повинна стати частиною національної програми [1].

Сьогодні українські заклади вищої освіти мають високий рівень економічної та фінансової несамостійності від бюджетних установ. Фінансова автономія усіх закладів $€$ надзвичайно важливою для залучення додаткових коштів для пошуку нових підходів до фінансової політики та управління. Фінансова автономія ЗВО досягається шляхом виконання замовлень від підприємств різних форм власності, а також замовлень фізичних осіб на платній основі, здійснення фінансових операцій (розміщення вільних фінансових коштів на депозитних рахунках у банку, випуск цінних паперів тощо), надання в оренду будівель, приміщень та обладнання, які знаходяться на балансі 3ВО, отримання державних та міжнародних грантів, залучення фінансових ресурсів від спонсорів та меценатів.

Таким чином, фінансова незалежність ЗВО, за умови ефективної організації процесу пошуку джерел додаткового фінансування, дозволить забезпечити необхідними коштами у достатньому обсязі. Варто зазначити, що фінансова незалежність ЗВО — це не відсторонення ЗВО від контролю держави, це можливість використання додаткових витрат на потреби вищої школи, які не може забезпечити держава в цілому або частково.

Сьогодні заклади освіти працюють в режимі, який забезпечують Бюджетний i Господарський кодекси, здебільшого вони лише частково користуються можливостями фінансової автономії й не несуть ринкової відповідальності за результати своєї діяльності. Разом з тим, політика оподаткування і контролю все ще не сприятлива для економічного розвитку. Нормативна база має створити умови, які дозволять закладам вищої освіти розвиватися, залучати додаткові кошти та не жити в режимі постійної економії. Як варіант, така позиція може грунтуватися на принципі звільнення від оподаткування освітньої діяльності. Максимально спрощений режим оподаткування й управління має місце також для наукової діяльності та інновацій.

3. Розробка механізму прогнозування потреби у спеціалістах певного напрямку.

Фінансування закладу освіти 3 розрахунку на студента, одна 3 найпоширеніших дискусій освітянського кола. Найпоширенішим в Україні підходом до фінансування ЗВО $\epsilon$ кошти спрямовані на фінансування освітньої інституції. При цьому, якість та ефективність надання освітніх послуг в першу чергу залежить від того, в якому обсязі фінансування доходить до здобувачів освіти та наскільки впливає на підвищення рівня отриманих знань. Це питання дуже тісно межує з питанням ефективності розподілу бюджетних коштів на підготовку фахівців та, як результат, соціально-економічного аспекту. Раціональний підхід до розподілу державного замовлення за напрямками підготовки є потужним інструментом формування кадрового внеску для майбутнього України. Необхідним етапом планування держзамовлення на підготовку здобувачів освіти є прогнозування потреб ринку праці. Потреби у фахівцях з вищою освітою необхідно вивчати у перспективі, це зумовлено щонайменше чотирирічним терміном підготовки студентів.

4. Удосконалення та розповсюдження програм державного кредитування та субсидіювання. 
У багатьох розвинутих країнах значно скоротилося державне фінансування освіти. Так, у Великій Британії, навчання у більшості закладів вищої освіти є платним і дорогим, при цьому відбувається шляхом надання населенню державних кредитів на освіту. В Україні також діють програми, які дозволяють отримувати кредити на пільгових умовах та державні субсидії на навчання. Можливість надання пільгового кредиту на навчання зазначена в Постанові КМУ «Про затвердження Порядку пільгового кредитування для здобуття професійно-технічної та вищої освіти» [2] і передбачають можливість отримання абітурієнтом державної фінансової допомоги на здобуття освіти.

Державні програми надання субсидій для студентів 3ВО можуть використовуватися в різних напрямках, зокрема, для осіб, які проживають в гуртожитках, виділяються кошти на відшкодування витрат за оплату користування житлом. Положення про порядок визначення та надання субсидій студентам ЗВО зазначено в постанові Кабінету Міністрів України «Про удосконалення порядку надання житлових субсидій» [3].

Головна мета обох програм подібна - громадянину України, що виявив бажання отримати вищу освіту за власний кошт, державою надається певна сума коштів, у кількості еквівалентній вартості навчання. Кредитні кошти надаються на пільгових умовах, з низьким відсотком (близько $3 \%$ річних) за умови погашення повної суми після здобуття диплому. За умови, що студент після здобуття освіти працюватиме в організації чи підприємстві державної форми власності, сума кредиту до виплати буде зменшуватись за кожен рік роботи. Це не єдині переваги від програм державного кредиту та субсидіювання освіти. Такий тип державної підтримки $є$ своєрідним гарантом працевлаштування здобувача освіти та заповнення робочих місць, що сприятиме покращенню економічної ситуації в державі.

\section{ВИСНОВКИ ТА ПЕРСПЕКТИВИ ПОДАЛЬШИХ ДОСЛІДЖЕНЬ}

На основі проведеного аналізу, метою якого є визначення можливостей підтримки та забезпечення дієвого фінансового забезпечення вищої освіти та стабілізації загальних умов існування 3ВО, було окреслено головні причини неефективності державного фінансування вищої школи, а також запропоновані шляхи подолання зазначених проблем.

Виконання вищевикладених кроків дасть можливість стабілізувати економічне становище, а також відкрити простір для подальшого розвитку. Сьогодення спричинює попит на підвищення темпів розвитку освіти та науки, що в майбутньому є прямою інвестицією в розвиток економіки держави.

Враховуючи значущість фінансового механізму ЗВО, як основоположної складової економіки держави, важливого значення набуває ретельний аналіз його ефективності, що дасть змогу виявити та виокремити негативні тенденції й окреслити напрямки та шляхи їх подолання. За для якісного моніторингу бюджетних витрат, фінансової стабільності та рівня фінансового менеджменту необхідне проведення аналізу використання фінансових ресурсів та визначення економічної ефективності.

\section{СПИСОК ВИКОРИСТАНИХ ДЖЕРЕЛ}

1. Співаковський О. Про стан фінансування освіти і науки [Електронний ресурс]. / Портал «Освіта.иа» — 17.11.2016. - Режим доступу: http://osvita.ua/blogs/53098/ (дата звернення: 01.12.2019

2. Постанова Кабінету Міністрів України «Про затвердження Порядку пільгового кредитування для здобуття професійно-технічної та вищої освіти»: станом на 07.08.2019 р. [Електронний ресурс]. Режим доступу: https://zakon.rada.gov.ua/laws/show/673-2018-п (дата звернення: 01.12.2019) 
3. Постанова Кабінету Міністрів України «Про удосконалення порядку надання житлових субсидій»: станом на 19.11.2019 p. [Електронний ресурс]. — Режим доступу: https://zakon.rada.gov.ua/laws/show/106-2015-п (дата звернення: 01.12.2019)

4. Сафонова В. Є. Удосконалення фінансово-економічного механізму функціонування закладів вищої освіти / В. С. Сафонова // Стратегічні пріоритети: зб. наук. праць Національного інституту стратегічних досліджень. - К., 2009. — № 2 (11). — С. 102-109.

5. Основні показники діяльності вищих навчальних закладів України на початок 2012/13 навчального року // Статистичний бюлетень. - К., 2013. - 169 с.

6. Основні показники діяльності вищих навчальних закладів України на початок 2013/14 навчального року // Статистичний бюлетень. - К., 2014. - 204 с.

7. Основні показники діяльності вищих навчальних закладів України на початок 2014/15 навчального року // Статистичний бюлетень. - К., 2015. - 219 с.

8. Основні показники діяльності вищих навчальних закладів України на початок 2015/16 навчального року // Статистичний бюлетень. — К., 2016. — 188 с.

9. Основні показники діяльності вищих навчальних закладів України на початок 2017/18 навчального року // Статистичний бюлетень. - К., 2018. - 165 с.

10. Ramskyi, A., \& Ramskyi, Y. (2017). Problems and tendencies of development of education in information society. Scientific Journal of Polonia University, 22(3), 89-95. https://doi.org/10.23856/2211 


\section{Обушный Сергей Николаевич}

кандидат экономических наук, заместитель декана

факультета информационных технологий и управления

Киевского университета имени Бориса Гринченка,

г. Киев, Украина

ORCID ID: 0000-0001-6936-955X

e-mail:s.obushnyi@kubg.edu.ua

\section{Кучеровская Виктория Александровна}

соискатель степени магистр

Киевский университет имени Бориса Гринченка,

г. Киев, Украина

e-mail:v.kucherovska@gmail.com

\section{СОВЕРШЕНСТВОВАНИЕ ФИНАНСИРОВАНИЯ ОБРАЗОВАТЕЛЬНОЙ ДЕЯТЕЛЬНОСТИ УЧРЕЖДЕНИЙ ВЫСШЕГО ОБРАЗОВАНИЯ В УКРАИНЕ}

Аннотация. В статье рассмотрены основные задачи финансового обеспечения деятельности учреждений высшего образования, дана характеристика и анализ действующей системы, разработаны рекомендации урегулирования уровня финансового обеспечения отдельного учреждения высшего образования и системы высшего образования в целом.

При исследовании выявлено, что сфера деятельности учреждений высшего образования не имеет возможности развиваться без надлежащего финансирования и требует постоянных вложений. Процесс реформирования системы высшего образования не является простым, потому что несмотря на обновления, новые требования и потребности, финансирование остается достаточно низким. Так все большую актуальность приобретает поиск альтернативных источников финансирования высших учебных заведений. Изучение недостатков системы финансирования учреждений высшего образования позволяет выделить перечень предложений, по трансформации финансового состояния.

На основании проанализированного опыта зарубежных стран, определены условия, при которых его можно имплементировать для украинского общества; предложен ряд мер для оценки результативности финансового механизма высших учебных заведений; учитывая сравнительный анализ и влияние экономических факторов.

Определено, что для преодоления проблем финансирования образовательной деятельности учреждений высшего образования нужно реализовать комплекс мероприятий, а именно: разработать систему трансформации внутренних процессов, внести изменения в законодательных документов, в том числе и в порядок финансирования; разработать механизмы определения потребности в определенных специалистах через определенные промежутки времени; совершенствовать и распространять программы государственного кредитования и субсидирования.

Движение в направлении современных экономических и социальных сдвигов, переход к инновационному типу экономики - это стопроцентно правильный путь для нашего государства. Несмотря на большое давление на систему высшего образования и постоянные требования необходима концентрация всех возможных усилий в направлении повышения эффективности деятельности высших учебных заведений. На государственном уровне необходимо создание требований для осуществления, возложенных на учреждение высшего образования обязанностей, преодолевая тотальную нехватку финансовых ресурсов, направленных в данную сферу.

Ключевые слова: бюджетное финансирование; учреждения высшего образования; механизмы финансирования; образовательные услуги; финансовое обеспечение. 


\author{
Sergiy Obushnyi \\ Ph.D. (Economics), deputy dean, \\ Information technology and management Faculty, \\ Borys Grinchenko Kyiv University, \\ Kyiv, Ukraine \\ ORCID ID: 0000-0001-6936-955X \\ e-mail: s.obushnyi@kubg.edu.ua \\ Viktoriia Kucherovska \\ Master of Science Degree, \\ Borys Grinchenko Kyiv University, \\ Kyiv, Ukraine \\ e-mail:v.kucherovska@gmail.com
}

\title{
IMPROVEMENT OF FINANCING OF EDUCATIONAL ACTIVITIES OF HIGHER EDUCATION INSTITUTIONS IN UKRAINE
}

Annotation. The article studies the main matters of financial support of the institutions of higher education activities, provides characteristic and analysis of the current system, developed recommendations for regulating the level of financial support of the specific institution of higher education and the higher education system as a whole.

The study revealed that the field of activity of higher education institutions is not able to increase and make progress without relevant funding and constant investment. Due to insufficient funding the reformation process of higher education system is rather complex despite of updates, new requirements and needs. Therefore, the search of alternative sources of funding of higher education institutions is becoming a pressing case. The research of insufficiency of the financing system of higher education institutions allows us to highlight the list of proposals on transformation of the financial situation.

Based on the analyzed experience of foreign countries, determined conditions that allow to implement it in Ukrainian society; proposed the set of measures for assessment the effectiveness of the financial mechanism of higher education institutions; given the comparative analysis and the influence of economic factors.

It was determined that in order to overcome the problems of financing the educational activities of higher education institutions, it is necessary to implement the set of measures, specifically: to develop the system of transformation of internal processes, to amend legislative documents, including the financing procedure; to develop mechanisms of determining the needs in the certain specialists within the certain intervals; to improve and distribute the state crediting and subsidy assistance programs.

The movement in the direction of modern economic and social shifts, the transition to an innovative type of economics is the absolutely right way for our Country. The concentration of all possible efforts is crucial in order to increase the effectiveness of higher education institutions, despite the great pressure on the higher education system and constant requirements. Moreover, it is necessary to create requirements to implement the assigned responsibilities to the institution of higher education, overcoming the total lack of financial resources allocated to this field.

Key words: budget financing; higher education institutions; financing mechanisms; educational services; financial provision.

\section{REFERENCES (TRANSLATED AND TRANSLITERATED)}

1. Spivakovskyi, O. (2016). On the state of financing of education and science. Osvita.ua. Retrieved 1 December 2019, from http://osvita.ua/blogs/53098/.

2. On Approval of the Procedure of Preferential Lending for Vocational, Technical and Higher Education. The legislation of Ukraine. (2019). Retrieved 3 December 2019, from https://zakon.rada.gov.ua/laws/show/6732018-П.

3. Resolution of the Cabinet of Ministers of Ukraine "On Improving the Procedure for Housing Subsidies", The legislation of Ukraine. (2019). Retrieved 3 December 2019, from https://zakon.rada.gov.ua/laws/show/106-2015-п

4. Safonova, V. (2009). Improvement of financial and economic mechanism of functioning of higher education institutions. Stratehichni Priorytety Zb. Nauk. Prats Natsionalnoho Instytutu Stratehichnykh Doslidzhen, 2(11), 102-109. Retrieved 1 December 2019, from.

5. State Statistics Service of Ukraine. (2013). Main indicators of activity of higher educational establishments of Ukraine at the beginning of 2012/13 academic year (p. 188). 
6. State Statistics Service of Ukraine. (2014). Main indicators of activity of higher educational establishments of Ukraine at the beginning of 2013/14 academic year (p. 204).

7. State Statistics Service of Ukraine. (2015). Main indicators of activity of higher educational establishments of Ukraine at the beginning of 2014/15 academic year (p. 219).

8. State Statistics Service of Ukraine. (2016). Main indicators of activity of higher educational establishments of Ukraine at the beginning of 2015/16 academic year (p. 188).

9. State Statistics Service of Ukraine. (2018). Main indicators of activity of higher educational establishments of Ukraine at the beginning of 2017/18 academic year (p. 165).

10. Ramskyi, A., \& Ramskyi, Y. (2017). Problems and tendencies of development of education in information society. Scientific Journal of Polonia University, 22(3), 89-95. https://doi.org/10.23856/2211 